\title{
HrpG and HrpX Play Global Roles in Coordinating Different Virulence Traits of Xanthomonas axonopodis pv. citri
}

\author{
Yinping Guo, ${ }^{1}$ Francisco Figueiredo, ${ }^{2}$ Jeffery Jones, ${ }^{2}$ and Nian Wang1 \\ ${ }^{1}$ Citrus Research and Education Center, Department of Microbiology and Cell Sciences, University of Florida, 700 Experiment \\ Station Road, Lake Alfred 33850, U.S.A.; ${ }^{2}$ Department of Plant Pathology, University of Florida, Gainesville 32611, U.S.A.
}

Submitted 15 September 2010. Accepted 21 January 2011.

Xanthomonas axonopodis pv. citri is the causal agent of citrus canker, which is one of the most serious diseases of citrus. To understand the virulence mechanisms of $X$. axonopodis pv. citri, we designed and conducted genomewide microarray analyses to characterize the HrpG and HrpX regulons, which are critical for the pathogenicity of $X$. axonopodis pv. citri. Our analyses revealed that 232 and 181 genes belonged to the HrpG and HrpX regulons, respectively. In total, 123 genes were overlapped in the two regulons at any of the three selected timepoints representing three growth stages of $X$. axonopodis pv. citri in XVM2 medium. Our results showed that HrpG and HrpX regulated all 24 type III secretion system genes, 23 type III secretion system effector genes, and 29 type II secretion system substrate genes. Our data revealed that $X$. axonopodis pv. citri regulates multiple cellular activities responding to the host environment, such as amino acid biosynthesis; oxidative phosphorylation; pentose-phosphate pathway; transport of sugar, iron, and potassium; and phenolic catabolism, through HrpX and HrpG. We found that 124 and 90 unknown genes were controlled by HrpG and HrpX, respectively. Our results suggest that HrpG and HrpX interplay with a global signaling network and co-ordinate the expression of multiple virulence factors for modification and adaption of host environment during $X$. axonopodis pv. citri infection.

The genus Xanthomonas is an important group of gramnegative plant-pathogenic bacteria that infect approximately 124 monocotyledonous and 268 dicotyledonous plants (Chan and Goodwin 1999; Leyns et al. 1984). Among the diseases caused by members of the genus Xanthomonas, citrus canker is one of the most serious diseases of most commercial citrus cultivars resulting in significant losses worldwide. Citrus-producing areas without citrus canker consider the citrus canker pathogen a quarantine pest due to the potential threat to citrus production. Thus, citrus canker has a significant impact on national and international citrus markets and trade (Graham et al. 2004). This devastating disease is caused by Xanthomonas axonopodis pv. citri (syn. X. citri, X. campestris pv. citri, or X. citri subsp. citri) (Cubero and Graham 2002; Schaad et al.

Corresponding author: Nian Wang; E-mail: nianwang@crec.ifas.ufl.edu; Telephone: +1.863.956.1151; Fax: +1.863.956.4631.

* The $e$-Xtra logo stands for "electronic extra" and indicates that six supplementary tables and two supplementary figures are published online.
2006; Vauterin et al. 1995). The Asiatic form or A type of citrus canker is the most virulent and affects the widest range of hosts, including Citrus spp. and many closely related rutaceous plants. Citrus canker disease is characterized by formation of necrotic raised lesions on leaves, stems, and fruit. On heavily infected trees, citrus canker causes defoliation, twig dieback, general tree decline, blemished fruit, and premature fruit drop. X. axonopodis pv. citri infects citrus from rainsplashed inocula directly through stomata (especially windblown rain) or by wounds, and grows in the intercellular spaces of the spongy mesophyll (Graham et al. 2004). The genus Xanthomonas has become an important model organism for studying plant-microbe interaction and for understanding bacterial pathogenicity and virulence mechanisms (Büttner and Bonas 2010).

In Xanthomonas spp., the type III secretion system (T3SS) encoded by a cluster of hypersensitive response and pathogenicity ( $h r p$ ) genes is one critical pathogenicity factor. The expression of hrp genes is controlled by two regulators: HrpG and $\operatorname{HrpX}$. HrpG, as an OmpR family regulator, activates the expression of $h r c C$ and $h r p X$ in $X$. campestris pv. vesicatoria (Wengelnik et al. 1996b) or only $h r p X$ in X. campestris pv. campestris (Huang et al. 2009). HrpX, an AraC-type transcriptional activator, controls the expression of other hrp genes along with some effector genes (Astua-Monge et al. 2000; Wengelnik and Bonas 1996). The HrpG regulon has been extended beyond the hrp genes using cDNA-amplified fragment length polymorphism (cDNA-AFLP) analysis (Noël et al. 2001). Thirty HrpG-induced and five HrpG-repressed genes were found, including the $h r p$ gene cluster, effector genes, and genes encoding protease. Many genes in the HrpX regulon in xanthomonads possess a consensus sequence motif, called the plant-inducible promoter (PIP) box (TTCGC-N15-TTCGC), in the promoter regions (Fenselau and Bonas 1995). Comparative genomic analysis revealed that 12 and 15 candidates for HrpX regulons existed in $X$. campestris pv. campestris and $X$. axonopodis pv. citri, respectively, which did not include the genes in hrp clusters (da Silva et al. 2002). However, genes with an imperfect PIP box and genes without a PIP box have been found to be controlled in an HrpX-dependent manner (Noël et al. 2001).

Recent studies showed that some type II secretion system (T2SS) substrate genes also belong to the HrpG or HrpX regulon (Furutani et al. 2004; Wang et al. 2008; Yamazaki et al. 2008). T2SS substrates, including proteases, lipases, and cellwall-degrading enzymes (CWDE), might contribute to bacterial infection by degradation of the plant cell wall. Co-regulation of T3SS and T2SS by HrpG and HrpX helps bacteria 
overcome plant defenses and acquire nutrients for growth in planta.

Although a few studies have been performed to identify genes in the HrpG or HrpX regulon, no comprehensive study has been done in genus Xanthomonas. In this study, we designed a genome-wide $X$. axonopodis pv. citri oligonucleotide microarray for the transcriptome analysis of the $\operatorname{HrpX}$ and HrpG regulons. Based on the microarray results, we expanded the knowledge about the HrpX and HrpG regulons with genes related to more functions such as chemotaxis and flagellar biosynthesis and transport, and a large set of unknown genes in addition to T3SS, effector, and T2SS substrate genes. We also found the cross-talk between HrpG regulatory cascade and quorum sensing $(\mathrm{QS})$.

\section{RESULT}

\section{Generation of the $h r p G$ mutant.}

The $h r p G$ insertion mutant was generated by double crossover homologous recombination in this study. The insertion of the kanamycin $(\mathrm{Km})$ cassette in $h r p G$ was confirmed by polymerase chain reaction (PCR) with three pairs of primers targeting different locations of inside and flanking regions of $h r p G$. The $h r p G$ insertion mutant lost pathogenicity in grapefruit and showed no symptoms (Supplementary Fig. S1). The complementation plasmid containing the intact $h r p G$ gene restored its pathogenicity in planta.

\section{Microarray analyses and validation of microarray data.}

It has been reported that, in Xanthomonas spp., the expression of hrp genes, including the regulators $h r p G$ and hrpX, was repressed in nutrient-rich media but strongly induced in planta and in nutrient-deficient medium XVM2, which is known to mimic the intercellular space of plant cells (Wengelnik et al.1996a). Therefore, XVM2 medium was selected to explore the HrpG and HrpX regulons of $X$. axonopodis pv. citri. The growth curves of both $h r p G$ and $h r p X$ mutants in XVM2 medium were similar to that of the wild-type strain (Supplementary Fig. S2).
In order to characterize the HrpG and HrpX regulons, microarray analyses were conducted to compare gene expression of the $h r p G$ or $h r p X$ mutants, respectively, with that of the wild-type strain 306 at different growth stages. The three timepoints used in this time-course study, A (optical density at 600 $\left.\mathrm{nm}\left[\mathrm{OD}_{600}\right]=0.25\right), \mathrm{B}\left(\mathrm{OD}_{600}=0.4\right)$, and $\mathrm{C}\left(\mathrm{OD}_{600}=0.5\right)$, represent three growth stages (two in exponential stage and one in early stationary stage) of $X$. axonopodis pv. citri in XVM2 medium. In this study, false discovery rate $(F D R)=0.05$ and absolute value of $\log _{2}$-fold change $=0.585$ (equivalent to fold change of 1.5) were used as the cut-off value. For the hrpG mutant, 99, 28, and 174 genes showed significant expression changes at timepoints A, B, and C, respectively (Fig. 1). Similarly, 53, 63, and 159 genes were differentially expressed in the $h r p X$ mutant at the three corresponding timepoints (Fig. 1). The greatest number of differentially expressed genes, and the greatest magnitude of changes, occurred at timepoint $\mathrm{C}$ in both mutants (Fig. 1). Overall, 232 genes belonged to the HrpG regulon, while 181 genes belonged to the HrpX regulon (Supplementary Table S1). HrpG and HrpX not only activated gene expression but also repressed gene expression. For the $h r p G$ mutant, 29, 9, and 95 genes were underexpressed and 70, 19, and 79 genes were overexpressed compared with the wild-type strain at timepoints A, B, and C, respectively. Similarly, 42, 58, and 104 genes were underexpressed and 11, 5, and 55 genes were overexpressed in the $h r p X$ mutant at the three corresponding timepoints (Fig. 1).

To validate the microarray data, two-step quantitative reverse-transcription (QRT)-PCR was used to verify the microarray data. Eight genes were chosen from among the genes belonging to both the HrpG and HrpX regulons to compare the data obtained from the two methods (Supplementary Table S2), which showed underexpression at timepoint $\mathrm{C}$ in both the $h r p G$ and $h r p X$ mutants in microarray analysis. The resulting transcriptional ratio from QRT-PCR analysis was $\log _{2}$ transformed and compared with the average $\log _{2}$ ratio values obtained by microarray analysis (Fig. 2). Although the amplitude of fold changes between the two techniques is different for different genes, the general trend of gene expression is consistent.

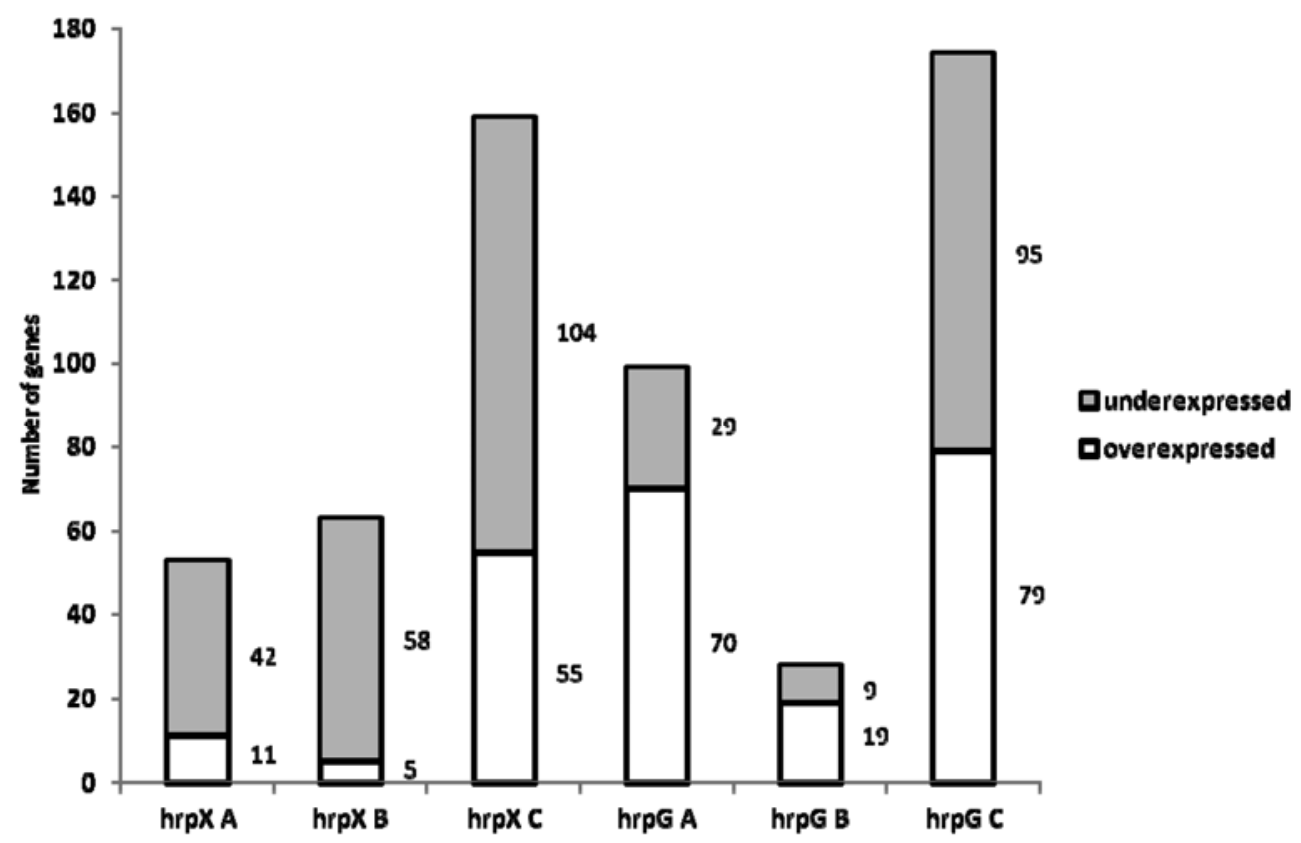

Fig. 1. Diagram displaying the numbers of differentially expressed genes resulting from the comparison of the hrpG mutant versus the wild-type strain and the $h r p X$ mutant versus wild-type strain at selected timepoints. Genes with the absolute value of $\log _{2}$-fold change $>0.585$ and false discovery rate $<0.05$ were selected as significantly differentially expressed genes. Black columns represent overexpressed genes in mutants and white columns represent underexpressed genes in either the $h r p X$ or $h r p G$ mutant. Numbers adjacent to the columns represent the numbers of genes in each condition. 
Functional classification of differentially regulated genes.

The 232 genes belonging to the HrpG regulon could be assigned to 18 functional categories according to the annotation from the J. Craig Venter Institute (JCVI) role categories, including amino acid biosynthesis; biosynthesis of cofactors, prosthetic groups, and carriers; cell envelope; cellular processes; central intermediary metabolism; DNA metabolism; energy metabolism; fatty acid and phospholipid metabolism; mobile and extrachromosomal element functions; protein fate; protein synthesis; regulatory functions; transcription; transport and binding proteins; hypothetical proteins; unknown function; unclassified, and not in JCVI (which means that the gene is not assigned to any JCVI categories) (Fig. 3). The 181 genes of the HrpX regulon were assigned into the same 17 functional categories as $\mathrm{HrpG}$, except mobile and extrachromosomal element functions. Approximately 53.4\% (124 of 232) of genes of the HrpG regulon and 49.7\% (90 of 181) genes of the HrpX regulon were in the categories of hypothetical protein, unclassified, unknown function, and not in JCVI.

\section{Clustering analysis.}

Clustering analysis was performed to group genes with a similar expression pattern. Genes with similar time-dependent regulation patterns were assigned to the specific clusters. This enables the characterization of clearer and more meaningful expression patterns from a large array of differentially regulated genes. Accordingly, five major gene clusters were assigned (Fig. 4).

Cluster I consisted of 104 genes showing underexpression in the $h r p X$ mutants at timepoint C. Of these, 73 were also underexpressed in the $h r p G$ mutant at timepoint $\mathrm{C}$. The genes in this cluster consist of genes encoding T3SS and T3SS effectors, T2SS substrates, and genes involved in amino acid biosynthesis, regulation pathway, and energy metabolism.

Cluster II was upregulated in both $h r p G$ and $h r p X$ mutants at timepoint $\mathrm{C}$. This cluster is composed of 31 genes, including those related to amino acid biosynthesis, DNA metabolism, and thiamine biosynthesis, and 23 hypothetical genes.

Cluster III was upregulated only in the $h r p G$ mutant at timepoint $\mathrm{C}$ but not in the $h r p X$ mutant at any stage. It comprises 44 genes encoding two-component regulation systems, chemotaxis and bacterial motility, amino acid biosynthesis, and sugar and starch metabolism.

Cluster IV was downregulated at any of the three timepoints of the $h r p G$ mutant but not in the $h r p X$ mutant. It contains 44 genes, including those related to energy metabolism, cell envelope, substrate transport and binding, and regulation.

Cluster V was upregulated in the $h r p X$ mutant only at timepoint $\mathrm{C}$ but not in the hrpG mutant. It includes 19 genes, consisting of those responsible for histidine biosynthesis, energy metabolism, and ABC transporter.

Genes not in clusters included 48 genes showing altered expression at least at one timepoint in either $h r p G$ or $h r p X$ mu-

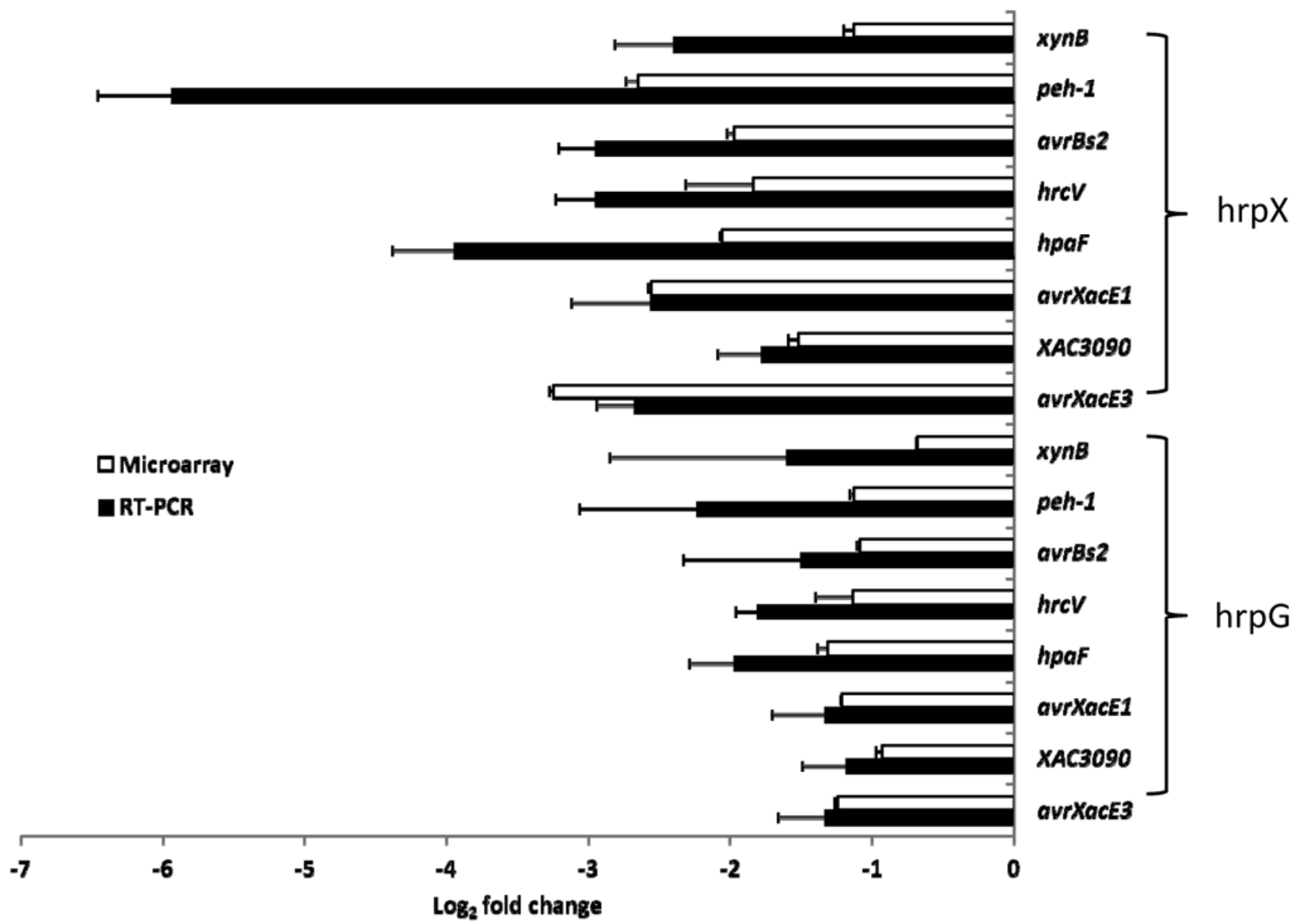

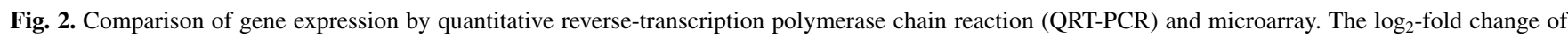
each gene was derived from the comparison of either $h r p X$ or $h r p G$ mutant versus wild-type at timepoint C. Two genes, $16 \mathrm{~S}$ rRNA and gyrA, were used as endogenous controls in QRT-PCR, both resulting in similar results. Only the QRT-PCR results with 16s rRNA as endogenous control are shown. Values of $\log _{2}$-fold change were means of four replicates. Experiments were repeated three times with similar results and only one result was presented. Error bars indicate standard deviation. White bars represent the values from microarray and black bars represent the values from QRT-PCR. 
tant. They encode proteins responsible for energy metabolism, regulation, substrate transportation, and pathogenicity factors (PthA1-4).

\section{T3SS and T3SS effectors.}

The whole hrp gene cluster, which contains 24 genes (XAC0393 to XAC0417), was downregulated in both $h r p G$ and $h r p X$ mutants. The magnitude of downregulation of $h r p$ genes in the $h r p X$ mutant was greater than that in the $h r p G$ mutant when compared at the same growth stage in XVM2. For instance, at timepoint $\mathrm{C}$, the expression of $h r p$ genes was downregulated 0.94 to $2.18 \log _{2}$-fold (1.92- to 4.53 -fold) in the hrpG mutant, whereas it was downregulated 1.23 to $5.54 \log _{2^{-}}$ fold (2.35- to 46.53-fold) in the $h r p X$ mutant. The expression of most putative and known T3SS effector genes was under HrpG and HrpX regulation. Among 24 putative and known T3SS effectors found in $X$. axonopodis pv. citri genome (Moreira et al. 2010b), 23 effectors belong to the HrpG or HrpX regulon (Supplementary Table S3). Except for the pthAl-4 and avrXacE2 genes, the remaining 18 effector genes were downregulated in both mutants and grouped into cluster I. The pthAl-4 genes showed altered expression (overexpressed) at timepoint $\mathrm{A}$ and $\mathrm{B}$ in the $\operatorname{hrp} G$ mutant while the avrXacE2 genes was overexpressed at timepoint $\mathrm{A}$ in the $h r p G$ mutant. HrpX did not regulate the expression of $p t h A$ and avrXacE2 genes. In addition, one putative effector gene, XAC2990, was identified in this study. The protein sequence of this gene shares $45 \%$ identity to the putative T3SS effector RCFBP_mp20163 from Ralstonia solanacearum (Remenant et al. 2010). The products of both genes have a lipase domain that hydrolyzes ester linkages of triglycerides. It was reported that lipase acted as a virulence factor and played important roles in disease development caused by Fusarium graminearum (Feng et al. 2005) and Pseudomonas aeruginosa (Reimmann et al. 1997). Two genes, XAC3225 and XACb0007, sharing 99\% identity with each other and encoding transglycosylase, belong to the HrpX regulon because their expression was downregulated in the $h r p X$ mutant at timepoint C. It was reported that XAC3225 shares high identity with hopAJl of
P. syringae pv. tomato DC3000, which is a T3SS helper protein contributing to effector translocation (Moreira et al. 2010b; Oh et al. 2007). Mutation of XAC3225 reduced the disease symptoms on citrus (Moreira et al. 2010b).

\section{T2SS substrates.}

Eight genes (Supplementary Table S4), including virK (XAC0435), XAC0552, phe-1 (XAC0661), xcp (XAC0795), $\mathrm{XAC} 0817$, pglA (XAC2374), XAC2831, and XAC2835, which have been confirmed to encode T2SS substrate experimentally, showed underexpression in both mutants except for pglA (XAC2374), which was underexpressed only in the hrpX mutant at timepoint C. Two of them, pglA (XAC2374) and phe-1 (XAC0661), encode CWDE. In addition, 21 genes were predicted as putative T2SS substrates in this study based on the clustering with the known T2SS substrates, homology to known secreted proteins, as well as signal peptide prediction. All 21 genes encoding putative T2SS substrates were upregulated by $\operatorname{HrpX}$, and 12 of them were also upregulated by HrpG. In addition, XAC2654 encoding a plant natriuretic peptide-like protein in $X$. axonopodis pv. citri (XacPNP) was underexpressed in both $h r p G$ and $h r p X$ mutants. Especially at timepoint $\mathrm{C}$ in the $h r p X$ mutant, its expression was more than five $\log _{2}$-fold lower than that in the wild-type strain.

\section{Signal transduction and regulation.}

Several genes belonging to the two-component system showed changed expression in this study (Table 1). Two genes encoding sensor kinases, XAC1488 and XAC2192, and two genes encoding response regulators, $r p f G$ (XAC1877) and XAC2897, were upregulated in the $h r p G$ mutant at timepoint C. Two genes (XAC1939 and XAC1940) encoding GGDEF family proteins showed an expression pattern similar to $r p f G$, which break down an important bacterial intracellular secondary messenger, 3,5-cyclic diguanylic acid (c-di-GMP). Gene regS (XAC1798) encoding a two-component system sensor protein showed overexpression in the $h r p G$ mutant at timepoint C. Gene stkXacl (XAC1171) encoding a serine/thre-

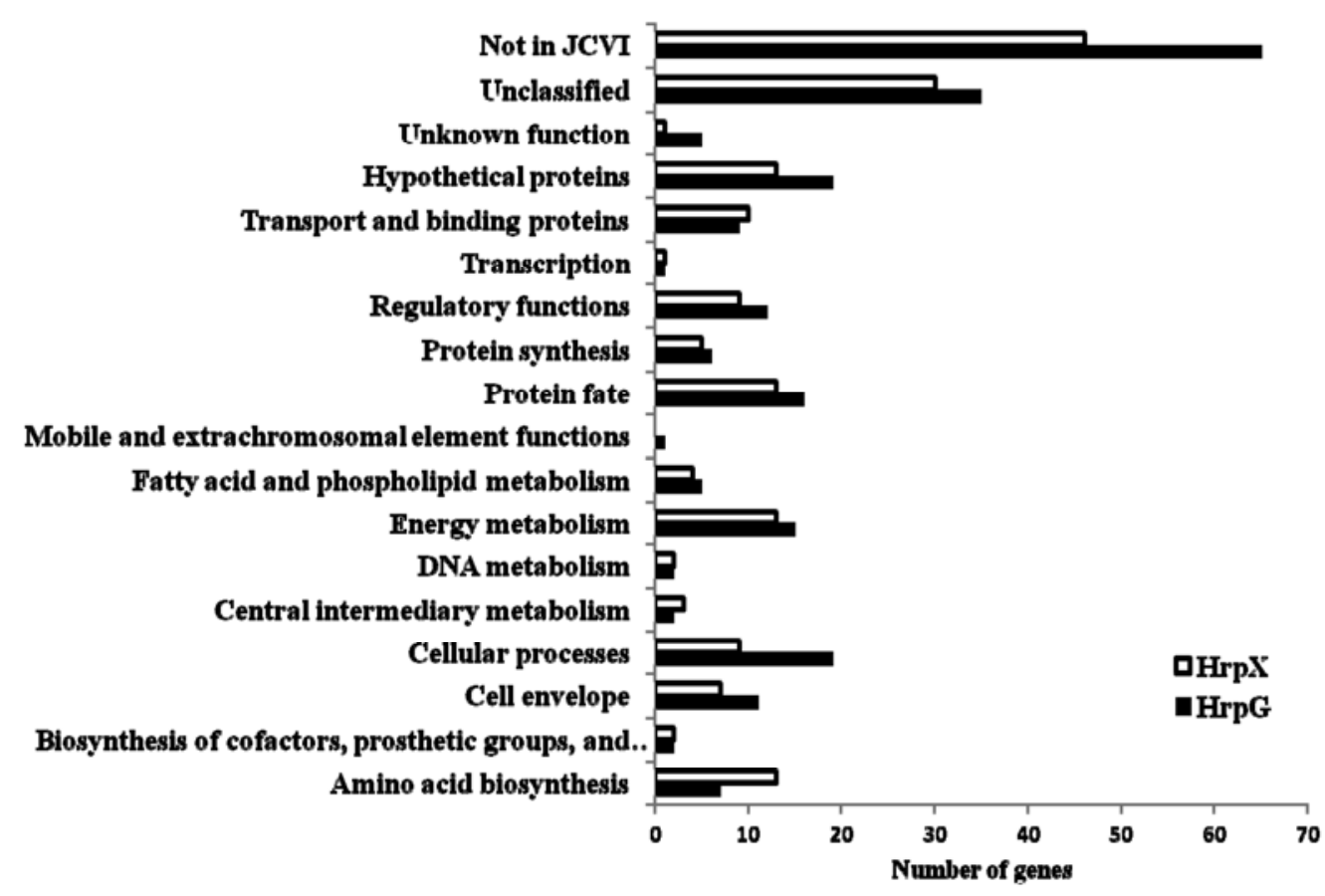

Fig. 3. Distribution of genes of the HrpG and HrpX regulons that were assigned into various J. Craig Venter Institute functional categories. White and black bars represent genes in the $\mathrm{HrpX}$ and HrpG regulon, respectively. * indicates biosynthesis of cofactors, prosthetic groups, and carriers. 
onine kinase showed underexpression in both mutants at timepoint C. Gene phoC (XAC4369) encoding phosphatase precursor was underexpressed in the $h r p X$ mutant at timepoint $\mathrm{C}$.

A few genes encoding transcriptional regulators were also differentially expressed in the study (Table 1). The expression of five genes (rpoE (XAC1682), XAC1555, XAC2166, $\mathrm{XAC} 3445$, and XAC4272) encoding one sigma factor RpoE and four transcriptional regulators was changed in the hrpX mutant. The expression of three transcriptional regulatory genes-XAC0917, phoU (XAC1573), and flgM (XAC1989)was changed only in the $h r p G$ mutant. Two genes encoding a transcription regulator, pcaQ (XAC0880) and XAC1455, showed altered expression in both $h r p X$ and $h r p G$ mutants.
Chemotaxis and bacterial motility.

A number of genes involved in motility and chemotaxis were regulated at transcription level in the $h r p G$ mutant. The fliJ gene (XAC1950), one of the flagellar genes whose product responds to chemotactic stimuli, was upregulated in the $h r p G$ mutant at timepoint A. Two genes, motB (XAC1908), encoding flagellar motor protein $\mathrm{D}$, and fliO (XAC1945), encoding flagellar protein for flagellum apparatus, were underexpressed in the $h r p G$ mutant at timepoint B. At timepoint $\mathrm{C}$, eight genes were overexpressed in the $h r p G$ mutant, including chemotaxis genes cheA (XAC2865), encoding chemotaxis histidine protein kinase, cheW (XAC1906), encoding a coupling protein, and cheY (XAC1904), encoding chemotaxis response regulator; and genes in early flagellar biosynthesis that are responsible

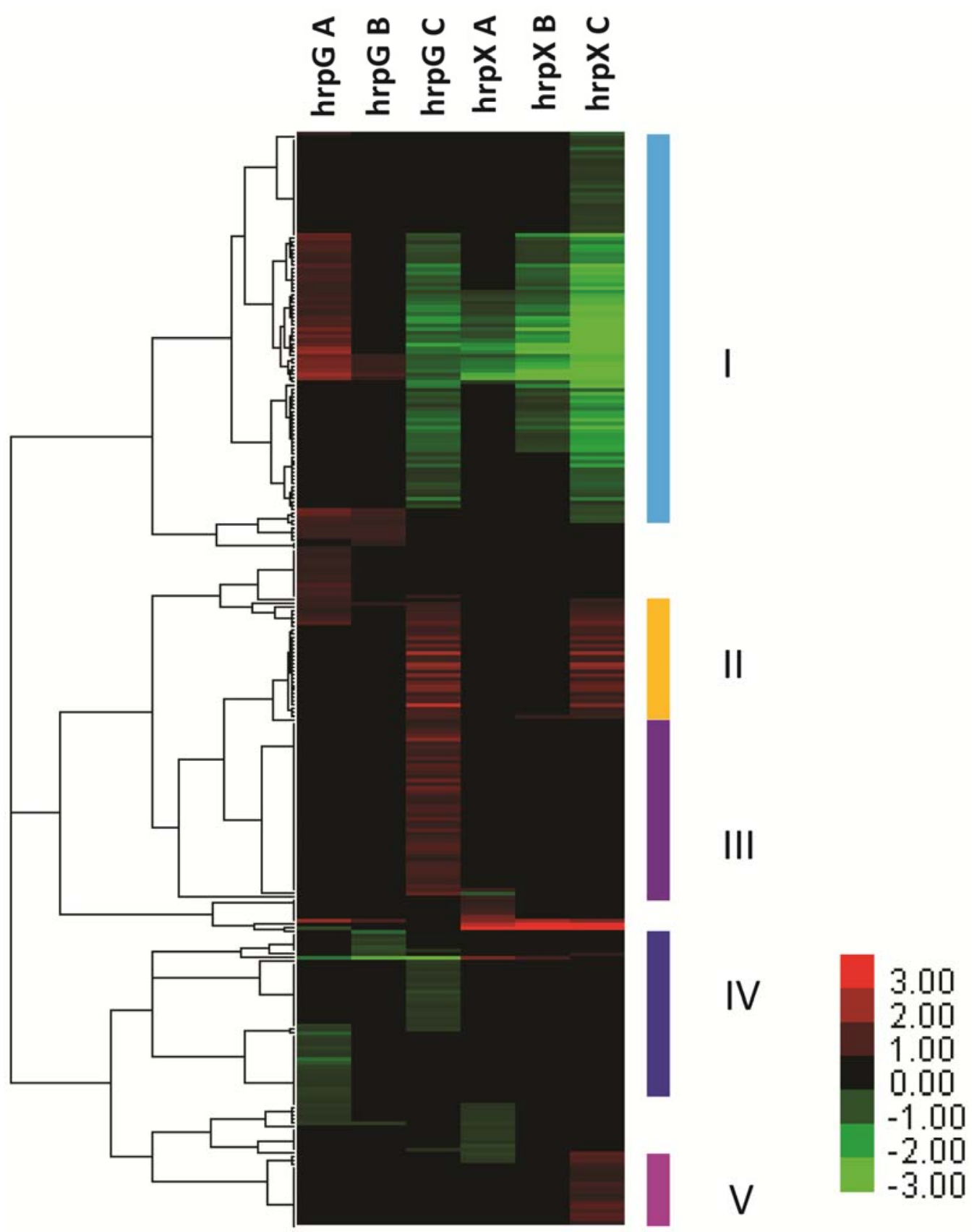

Fig. 4. Hierarchical clustering of genes in the HrpG and HrpX regulons based on similar time-dependent expression patterns. Clustering analysis was performed with Cluster 3.0 using complete linking with uncentered correlation distance. Columns represent individual timepoints and rows represent individual

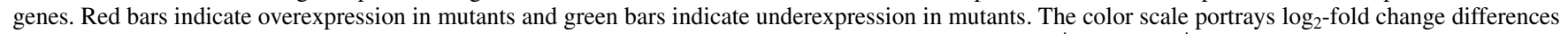
between the mutants and wild-type strains. Genes with the absolute values of $\log _{2}$-fold change $<0.585$ (|fold change $\mid<1.5$ ) were displayed in black. Five major clusters were assigned as I, II, III, IV, and V. 
for flagellum basal body assembly, such as $f l g F$ (XAC1982), encoding flagellar basal body rod protein, fliF (XAC1954), encoding flagellar M-ring protein, fliI (XAC1951), encoding flagellum-specific ATP synthase, and fliG (XAC1953) encoding flagellar motor switch protein. Gene flgM (XAC1989), encoding an anti- $\sigma-28$ factor that is a negative regulator of flagellin synthesis, was overexpressed in the $\operatorname{hrp} G$ mutant at timepoint C.

To test whether the expression changes of flagella genes we found from the microarray analysis led to motility changes in the $h r p G$ mutant, both swarming and swimming assays were performed on XVM2 plates containing either 0.7 or $0.3 \%$ agar. The $h r p G$ mutant did not show different swimming ability on XVM2 supplemented with $0.3 \%$ agar in the incubation period (data not shown). Higher swarming ability of the $h r p G$ mutant was observed after 13 days of inoculation on XVM2 containing $0.7 \%$ agar (Fig. 5). This result is consistent with the microarray analysis of the $h r p G$ mutant showing that most of the differentially expressed genes related to flagellar biosynthesis were changed at the early stationary stage.

\section{Amino acid biosynthesis.}

Sixteen genes related to amino acid biosynthesis showed altered expression in this study. Eight genes (XAC1828 to $X A C 1835)$ involved in histidine biosynthesis were upregulated only in the $h r p X$ mutant at timepoint $\mathrm{C}$. Two genes, ilvC (XAC3451) and ilvG (XAC3452), involved in valine, leucine, and isoleucine biosynthesis showed an expression pattern similar to that of histidine biosynthesis genes. Three genes-metE (XAC0336), involved in cysteine and methionine metabolism; dapA (XAC1760), involved in lysine biosynthesis; and asnB (XAC1433), involved in alanine, aspartate, and glutamate me- tabolism-showed expression changes in the hrpG mutant. Two genes involved in phenylalanine, tyrosine, and tryptophan biosynthesis-tyrA (XAC1525) and pheA (XAC3647)showed expression changes in both $h r p X$ and $h r p G$ mutants. PheA is a chorismate mutase, which is a key enzyme in the

\section{W $\mathrm{W}$ hrpG $\square \mathrm{hrpX}$}

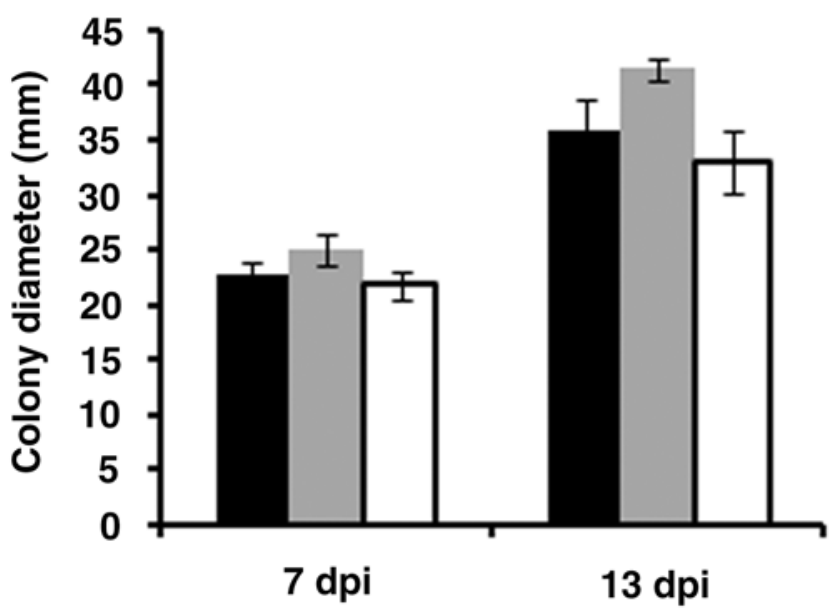

Fig. 5. Swarming assay on XVM2 medium containing $0.7 \%$ agar. Black columns represent wild-type strain, gray columns represent the $h r p G$ mutant, and white columns indicate the $h r p X$ mutant. dpi = days postinoculation. Experiments were performed in quadruplicate and repeated three times with similar results; only one representative result was presented.

Table 1. Regulatory genes under the control of HrpG and HrpX

\begin{tabular}{|c|c|c|c|c|c|c|c|c|c|}
\hline \multirow[b]{2}{*}{$\mathrm{JCVI}^{\mathrm{b}}$} & \multirow[b]{2}{*}{ Locus tag } & \multirow[b]{2}{*}{ Gene } & \multicolumn{6}{|c|}{$\log _{2}$ ratio of fold change ${ }^{a}$} & \multirow[b]{2}{*}{ Product description } \\
\hline & & & hrpGA/W & pGB/Y & rpGC/V & hrpXA/W & hrpXB/W & hrpXC/WC & \\
\hline \multicolumn{10}{|l|}{ Both } \\
\hline $\mathrm{R}$ & $\mathrm{XAC} 1171$ & stkXacl & 0.984 & NS & -1.031 & NS & -0.778 & -2.025 & Serine/threonine kinase \\
\hline $\mathrm{R}$ & XАC0880 & $p c a Q$ & 0.675 & NS & -0.854 & NS & -0.883 & -1.999 & Transcriptional regulator \\
\hline $\mathrm{R}$ & XAC1455 & $\ldots$ & 0.638 & NS & NS & NS & NS & -1.195 & MarR family transcriptional regulator \\
\hline \multicolumn{10}{|r|}{ 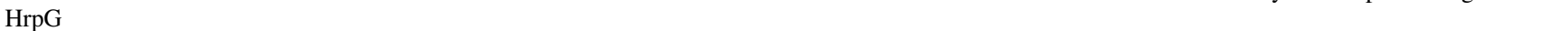 } \\
\hline $\mathrm{T}$ & XAC1320 & $\ldots$ & NS & NS & -0.716 & NS & NS & NS & Regulatory protein \\
\hline $\mathrm{U}$ & XAC1939 & $\ldots$ & NS & NS & 0.652 & NS & NS & NS & GGDEF family protein \\
\hline $\mathrm{R}$ & XAC3771 & $\ldots$ & NS & NS & 0.675 & NS & NS & NS & $\begin{array}{l}\text { Hypothetical protein; pfam03466-LysR } \\
\text { substrate binding domain }^{c}\end{array}$ \\
\hline $\mathrm{R}$ & XAC2192 & $\ldots$ & NS & NS & 0.759 & NS & NS & NS & Two-component system sensor protein \\
\hline $\mathrm{R}$ & XAC1877 & $r p f G$ & NS & NS & 0.780 & NS & NS & NS & Response regulator \\
\hline $\mathrm{U}$ & XAC1940 & $\ldots$ & NS & NS & 0.817 & NS & NS & NS & GGDEF family protein \\
\hline $\mathrm{R}$ & XAC1488 & $\ldots$ & NS & NS & 0.951 & NS & NS & NS & Sensor histidine kinase \\
\hline $\mathrm{R}$ & XAC1989 & $f \lg M$ & NS & NS & 0.995 & NS & NS & NS & Flagellar protein \\
\hline $\mathrm{R}$ & XАC2897 & $\ldots$ & NS & NS & 1.128 & NS & NS & NS & Response regulator \\
\hline $\mathrm{R}$ & XAC1573 & phoU & NS & NS & 1.139 & NS & NS & NS & $\begin{array}{l}\text { Phosphate regulon transcriptional } \\
\text { regulator }\end{array}$ \\
\hline $\mathrm{R}$ & XAC1798 & $r e g S$ & NS & 0.601 & NS & NS & NS & NS & Two-component system sensor protein \\
\hline $\mathrm{R}$ & XAC0917 & $\ldots$ & -0.734 & NS & NS & NS & NS & NS & Transcriptional regulator \\
\hline \multicolumn{10}{|r|}{ (1) } \\
\hline $\mathrm{R}$ & XAC2166 & $\ldots$ & NS & NS & NS & NS & NS & -1.021 & Transcriptional regulator \\
\hline $\mathrm{R}$ & XAC2163 & $\ldots$ & NS & NS & NS & NS & NS & -0.742 & $\begin{array}{l}\text { Hypothetical protein; pfam07969- } \\
\text { amidohydrolase familyc }\end{array}$ \\
\hline $\mathrm{R}$ & XAC3445 & $\ldots$ & NS & NS & NS & 2.221 & 2.879 & 3.457 & Transcriptional regulator \\
\hline $\mathrm{R}$ & XAC3446 & $\ldots$ & NS & NS & NS & -0.708 & NS & NS & $\begin{array}{l}\text { Hypothetical protein; pfam00486- } \\
\text { transcriptional regulatory protein, } \\
\mathrm{C} \text { terminal }^{\mathrm{c}}\end{array}$ \\
\hline $\mathrm{R}$ & XAC4272 & $\ldots$ & NS & NS & NS & -0.617 & NS & NS & LacI family transcription regulator \\
\hline $\mathrm{R}$ & XAC1555 & $\ldots$ & NS & NS & NS & -0.653 & NS & NS & Transcriptional regulator \\
\hline $\mathrm{T}$ & XAC1682 & rpoE & NS & NS & NS & NS & NS & -0.822 & RNA polymerase $\sigma$-E factor \\
\hline
\end{tabular}

${ }^{a}$ Fold change was derived from mutants versus wild type at timepoints A, B, and C. NS $=$ not significantly differentially expressed $\left(\mid \log _{2}\right.$-fold change $\mid<$ 0.585 or false discovery rate $>0.05$ ).

b J. Craig Venter Institute (JCVI) functional categories for HrpG and HrpX regulon (Both) or HrpG and HrpX regulons individually. Categories: R = regulatory functions, $\mathrm{T}=$ transcription, and $\mathrm{U}=$ unknown function.

${ }^{\mathrm{c}}$ Pfam analysis of the hypothetical proteins. 
shikimate pathway related to aromatic amino acid synthesis. It was reported that chorismate mutase was either translocated to the periplasm or secreted in some pathogenic bacteria (Calhoun et al. 2001; Sasso et al. 2005; Xia et al. 1993). The chorismate mutase found in $X$. oryzae pv. oryzae XKK.12 is involved in virulence on its host rice (Degrassi et al. 2010).

\section{General metabolism and transport.}

Many genes involved in general metabolism are regulated by HrpG and HrpX, including those involved in energy metabolism, fatty acid and phospholipid metabolism, and sugar transport. Three genes-GNL (XAC0548), fruK (XAC2502), and $k d g K$ (XAC0143) - involved in the pentose phosphate pathway were differentially expressed in the $h r p G$ mutant. Three genes encoding cytochrome $\mathrm{C}$ oxidase, which is the complex IV in oxidative phosphorylation, were underexpressed in both mutants at timepoint A. The atpB (XAC3655) gene in oxidative phosphorylation was overexpressed only in the $h r p X$ mutant at timepoint $\mathrm{C}$. Three genes in fatty acid and phospholipid metabolism-accD (XAC0264), fadE9 (XAC1313), and paaF (XAC1314)-were overexpressed in the hrpG mutant at timepoint $\mathrm{C}$. Gene paaF also showed overexpression in the $h r p X$ mutant at timepoint $\mathrm{A}$.

Thirteen genes encoding transport and binding proteins were differentially expressed in either $h r p G$ or $h r p X$ mutant. Four genes encoding TonB-dependent receptors (XAC3050, XAC3489, XAC3444, and XAC1143) showed differential expression. These proteins are assembled in the outer membrane of gram-negative bacteria and are mainly known in the transport of iron-siderophore complexes and vitamin B12 into the periplasm (Postle and Kadner 2003). In recent studies, novel substrates of TonB-dependent receptors were revealed, such as nickel, zinc, maltodextrin, and sucrose (Blanvillain et al. 2007; Neugebauer et al. 2005; Schauer et al. 2007; Stork et al. 2010). XAC3489 shares $93 \%$ identity at the amino acid sequence with XCC 3358, which plays a major role in pathogenicity. The XCC3358 insertion mutant of $X$. campestris pv. campestris showed delayed symptom development compared with the wild-type strain (Blanvillain et al. 2007). A few genes encoding transporters were differentially expressed in either the hrpG or $h r p X$ mutant, such as sugar transporters (e.g., fucP [XAC1556], sucl [XAC3488], and fruA [XAC2503]), $\mathrm{K}^{+}$ transporter $k d p C$ (XAC0758), ABC transporter components (XAC 0827 to XAC0828), and MFS transporter (XAC1705).

\section{DISCUSSION}

DNA microarray has been widely used to study the transcriptional responses of many organisms to genetic and environmental perturbations (Dharmadi and Gonzalez 2004; Ye et al. 2001). In this study, we developed the first whole-genome DNA microarray for $X$. axonopodis pv. citri. In previous studies, two gene-array platforms for expression analysis have been designed and have played important roles in characterization of the pathogenicity and virulence of $X$. axonopodis $\mathrm{pv}$. citri (Astua-Monge et al. 2005; Moreira et al. 2010a). However, both previous gene arrays represented part of the genome. The first $X$. axonopodis pv. citri gene array is a macroarray that only contains $279 X$. axonopodis pv. citri genes associated with pathogenicity and virulence (Astua-Monge et al. 2005), while the second $X$. axonopodis pv. citri gene array only consists of 2,365 open reading frames (ORF), which correspond to $52.7 \%$ of the annotated ORF of the $X$. axonopodis pv. citri genome (Moreira et al. 2010a). The microarray developed in our study represents all 4,427 annotated protein-coding ORF. In addition, we used an 8-by-15-K format so that eight microarrays could be printed on a single slide, which will significantly reduce the variation when multiple slides are used (Tseng et al. 2001). The reliability of this array has been proven with the following evidence: i) gene expression of all selected genes in the microarray result was validated in QRT-PCR (Fig. 2); ii) T3SS and T3SS effector genes that have been shown to be regulated by HrpX and HrpG (Wengelnik and Bonas 1996; Wengelnik et al. 1996b, 1999) were identified in our study (Fig. 4); and iii) T2SS substrate genes that have been shown to be controlled by HrpX and HrpG were confirmed using this microarray. Thus, our microarray provides a robust and comprehensive tool for transcriptome analysis of $X$. axonopodis $\mathrm{pv}$. citri.

HrpX and HrpG play important roles in coordinating different categories of genes. First, they regulate pathogenicity and virulence genes to overcome the plant defense responses and survive in the intercellular spaces. The most well-known HrpG- and HrpX-dependent virulence factors were distributed in cluster I (Fig. 4), including T3SS ( $h r p$ genes), T3SS effectors, T2SS substrates, and XacPNP. The major roles of T2SS substrates include degradation of the plant cell wall, cytotoxicity, adherence, spread, and transmission (Cianciotto 2005), which might facilitate the assembly of extracellular appendages of secretion systems such as T3SS and, therefore, promote pathogenesis. T3SS translocates the T3SS effector proteins into plant cells that either suppress the host defense or interfere with host cellular processes. For instance, some T3SS effectors act as cysteine proteases in plants such as XopD, a member of the YopJ/AvrRxv family (Grant et al. 2006; Noël et al. 2002). Members of the AvrBs3/PthA family of transcriptional factors directly interact with the host transcription to modulate the host gene expression (Schornack et al. 2006). Our microarray data showed that $p t h A 1-4$ genes were not controlled by HrpX. However, the expression of pthA1-4 genes was induced in the $h r p G$ mutant at timepoint A and B. $X$. axonopodis pv. citri employs XacPNP to mimic host PNP and to systemically regulate plant homeostasis, resulting in a suppressed host defense responses and better survival environment for bacteria (Gottig et al. 2009). Importantly, a significant induction of $h r p G$ expression was observed when Xanthomonas spp. enter the plant apoplast (Zhang et al. 2009). Thus, HrpG coordinates multiple virulence factors in the $X$. axonopodis pv. citri infection process. Second, in addition to manipulation of plant defenses, $X$. axonopodis pv. citri has to adapt its metabolism to the intercellular spaces, which are nutrient poor (Alfano and Collmer 1996) and laden with toxic substances (either preformed or induced) as part of the host defense responses (Osbourn 1996; Segura et al. 1999). Multiple intracellular metabolic activities, such as amino acid biosynthesis; oxidative phosphorylation; pentose-phosphate pathway; transport of sugar, iron, and potassium; and the phenolic compounds catabolism pathway are regulated through $\mathrm{HrpX}$ and HrpG to help the bacteria to overcome environmental stresses. $X$. axonopodis pv. citri activates the gene expression of sugar transporters through HrpX and HrpG in order to uptake more sugars as a carbon and energy source, particularly sucrose, glucose, and fructose, which are the most common sugars in the plant apoplast (Joosten et al. 1990; Rico et al. 2009). The activation of a phenolic catabolism pathway could convert toxic plant chemicals to less toxic compounds or even carbon sources. Third, we also identified a large set of unknown genes controlled by HrpG and HrpX. In all, 53.4\% (124 of 232) of genes in the HrpG regulon and $49.7 \%$ (90 of 181) of genes in the HrpX regulon encode unknown proteins. Their roles are unknown in $X$. axonopodis pv. citri infection. Nonetheless, the list might provide targets for further study. Among the unknown proteins, some seem to play important roles in $X$. axonopodis pv. citri virulence. For example, one putative 
effector gene, XAC2990, was predicted in this study. The protein sequence of this gene shares $45 \%$ identity with the putative T3SS effector RCFBP_mp20163 from $R$. solanacearum (Remenant et al. 2010).

The regulation of HrpX and HrpG on multiple cellular activities is through both direct and indirect controls (Fig. 6). For the T3SS and T3SS effector genes, five T3SS genes and eight T3SS effector genes have been shown to contain PIP boxes in their promoter regions (da Silva et al. 2002). HrpX was shown to interact with the PIP box (Koebnik et al. 2006). For other genes controlled by HrpX and HrpG but without PIP box, one putative explanation is that HrpX and HrpG control multiple regulatory genes (Table 1; Fig. 6), which, in turn, regulate those genes. In total, HrpX and HrpG manipulate the gene expression of 21 regulatory genes and one sigma factor gene (Table 1). Among the regulatory genes controlled by HrpG, rpfG encodes a response regulator (discussed below) in the diffusible signal factor (DSF)-mediated QS system (Barber et al. 1997; Tang et al. 1991). RpfG was reported to regulate genes involved in synthesis of extracellular enzymes and exopolysaccharide (EPS) and biofilm formation (Slater et al. 2000). The regulation of flagellar genes might be related to the regulation of $f l g M$ and XAC0917 by HrpG. Gene flgM (XAC1989) overexpressed in the $h r p G$ mutant at the early stationary stage, which encodes an anti- $\sigma-28$ factor that is involved in temporal regulation of flagellar biosynthesis (Yang et al. 2009). XAC0917 is a TetR family member. It was reported that FhrR, a TetR family member, positively regulates expression of the genes encoding flagellar and ribosomal protein genes and negatively regulates expression of $h r p$ genes under the control of Clp in X. campestris pv. campestris (He et al. 2007). The phoU gene encodes a transcriptional regulator, which partici-

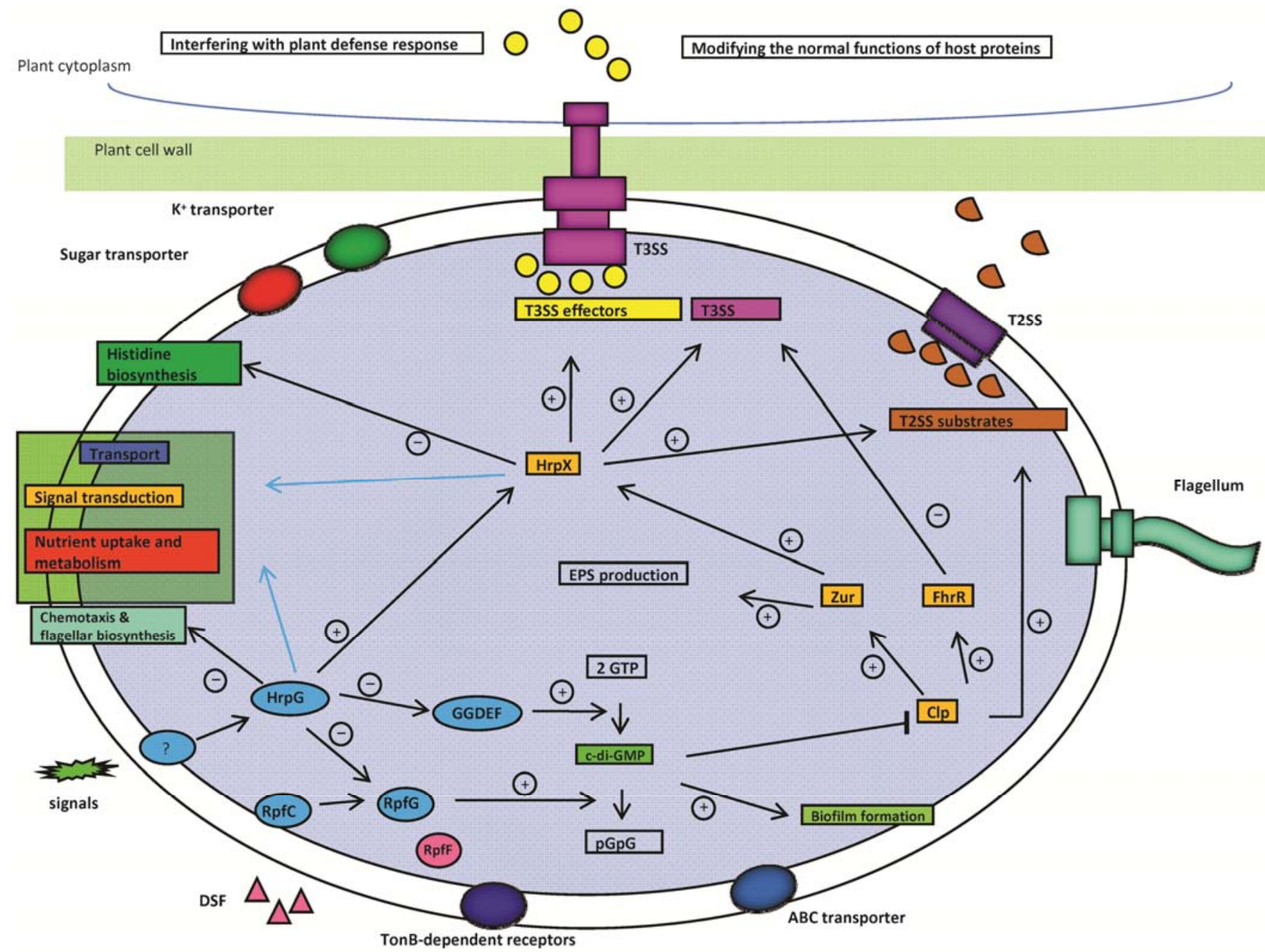

Fig. 6. Schematic model of HrpG- and HrpX-related regulation cascades of Xanthomonas genus. The environmental or plant signals activate the unknown sensor protein which relays the signal to the master regulator HrpG. The activated HrpG is involved in four major aspects of regulatory cascades: 1) Inducing the transcription of HrpX, which in turn activates the expression of a large set of virulence genes such as T3SS, T3SS effector, and T2SS substrate genes. HrpX represses the transcription of genes involved in histidine biosynthesis at the same time. During this process, HrpX also regulates the transcription of some genes involved in signal transduction and regulation such as transcriptional factors, as well as transport which may result in change of nutrient uptake and energy metabolism. 2) HrpG represses the transcription of genes involved in chemotaxis and flagellar biosynthesis in order to repress bacterial motility at the early stationary stage of growth. 3) HrpG also controls the expression of genes related to signal transduction and regulation, transport and general metabolism. 4) HrpG cross-talks with DSF-mediated quorum sensing pathway via repressing the transcription of RpfG and two GGDEF proteins at the early stationary stage of growth. Those proteins contribute the concentration of the central messenger cyclic-di-GMP. The high levels of c-di-GMP promote biofilm formation, while low levels promote motility and transcription of virulence factors. One important target of c-di-GMP is Clp which is a transcriptional activator. C-di-GMP binds to the Clp to prevent it from DNA binding and the expression of genes encoding extracellular enzymes, and genes involved in T3SS, and EPS biosynthesis. Two transcriptional factors, FhrR and Zur are under the control of Clp and they have regulatory effect on expression of the $h r p$ genes. Blue lines indicate both positive and negative regulations occurring in different genes of the listed functional categories. + and - represent positive and negative transcriptional regulation, respectively. 
pates in phosphate transport and also negatively controls the expression of phosphate ABC transporter genes (Muda et al. 1992). The stkXacl(XAC1171) gene encodes a seine/threonine kinase, which plays important roles in a multitude of cellular processes, including division, proliferation, apoptosis, and differentiation (Manning et al. 2002). The HrpX and HrpG regulons also manipulates the gene expression of multiple regulators, including pcaQ (XAC0880), XAC1455, XAC1555, XAC4272, XAC3445, and XAC2166, which have not been studied extensively in $X$. axonopodis pv. citri. However, their homologs have been studied in other bacteria. For example, the homolog of PcaQ (XAC0880), a LysR-family transcription regulator, activated the expression of the pcaDCHGB operon, which encodes enzymes involved in phenolic compounds catabolism in Agrobacterium tumefaciens A348, (Parke 1996). In agreement with the regulation of $\mathrm{PcaQ}$, two genes encoding subunits of protocatechuate 4,5-dioxygenase, pcaH (XAC0878) and ligA (XAC0879), were underexpressed in both hrpX and $h r p G$ mutants. Protocatechuate 4,5-dioxygenase is the first enzyme in the protocatechuate branch of the $\beta$-ketoadipate pathway to use aromatic compounds as carbon sources (Parke 1996). XAC 1455 shares $85 \%$ identity of amino acid sequence with XC_2827, which belongs to the MarR family transcriptional regulator in $X$. campestris pv. campestris 8004 . The product of XC_2827, designated as HpaR, is involved in hypersensitive response, pathogenicity, and extracellular protease production in $X$. campestris pv. campestris and was positively regulated by HrpG and HrpX (Wei et al. 2007). Thus, it seems that HrpX and HrpG control multiple cellular activities through multiple regulatory genes.

Our data suggest that a cross-talk exists between HrpG and the QS system in $X$. axonopodis pv. citri. The rpfG gene (XAC1877) was upregulated at the early stationary stage in the hrpG mutant. Two GGDEF genes showed expression patterns similar to $r p f G$, which break down an important bacterial intracellular secondary messenger, c-di-GMP. RpfG is the response regulator in the DSF-mediated QS system, which mediates virulence, biofilm formation, and many cellular activities in Xanthomonas spp. (Barber et al. 1997; Tang et al. 1991). RpfG contains an HY-GYP domain, which interacts with GGDEF proteins to mediate signal transduction to c-di-GMP. The cross-talk between DSF-mediated QS and the HrpG regulon was also found in genome-scale analysis of the DSF regulon in $X$. campestris pv. campestris (He et al. 2006, 2007). In addition, for the $h r p G$ mutant, 99, 28, and 174 genes showed significant expression changes at timepoints $\mathrm{A}, \mathrm{B}$, and $\mathrm{C}$, respectively (Fig. 3). Similarly, 53, 63, and 159 genes were differentially expressed in the $h r p X$ mutant at the three corresponding timepoints (Fig. 3). The temporal changes of gene regulation might be related to QS. QS is likely to be involved in controlling the timing and level of gene expression in the HrpG regulon. Bacteria might monitor cell density and host stimuli by timing the expression of virulence factors such as T3SS. The messenger c-di-GMP might be the molecule that links QS and the HrpG regulatory cascade. RpfG and GGDEF proteins control the concentration of the central messenger, c-di-GMP. The high levels of c-di-GMP promote biofilm formation, whereas low levels promote motility and transcription of virulence factors (Römling et al. 2005; Simm et al. 2004; Tischler and Camilli 2004). One important target of c-di-GMP is the cAMP receptor protein-like protein $(\mathrm{Clp})$, which is a transcriptional activator. C-di-GMP binds to the Clp to prevent DNA binding and the expression of genes encoding extracellular enzymes and genes involved in T3SS and EPS biosynthesis (He et al. 2007). Two transcriptional factors, FhrR and Zur, were identified in the transcriptomic analysis of Clp regulons of $X$. campestris pv. campestris (He et al. 2007). FhrR controls the expression of genes encoding flagellar, T3SS, and ribosomal proteins, while Zur regulates genes involved in iron uptake, multidrug resistance, and detoxification (Huang et al. 2009). Therefore, it is possible that bacteria temporally regulate the cellular functions to adapt to different stages of growth or infection through multiple signaling cascades, including the QS system.

Comparison of the HrpX and HrpG regulons at different timepoints gives us an insight into the dynamic expression of common genes shared by both regulons. In all, 33 genes were shared by the two regulons at timepoint $\mathrm{A}$ and 9 genes at timepoint B, whereas 104 common genes were found at timepoint C (Supplementary Table S5). In general, 123 genes were overlapped in the two regulons at any of the three timepoints, which corresponds to $68 \%$ of the HrpX regulon (123 of 181), and $53 \%$ of the HrpG regulon (123 of 232). The most common genes were grouped into cluster I, which contains genes encoding T3SS, T3SS effectors, and T2SS substrates. Interestingly, 58 genes in the HrpX regulon are HrpG independent, while 109 genes in the HrpG regulon are HrpX independent. As to the HrpG-independent genes in the HrpX regulon, further analysis revealed that 23 of them showed subtle expression changes (the absolute value of $\log _{2}$-fold change $<0.585$ ), with statistical significance FDR $<0.05$ in the $h r p G$ mutant in at least one of the three timepoints (particularly 17 of the 23 genes are in cluster I). The expression of genes in cluster I responded to $h r p X$ mutation more rapidly and dramatically than to HrpG mutation based the $\log _{2}$-fold value (Fig. 4). Thus, those 23 genes might also belong to the HrpG regulon but have weaker responses to HrpG. For the remaining $35 \mathrm{HrpG}$-independent genes in the HrpX regulon, one possibility is that the $h r p X$ gene is regulated by other regulators besides HrpG. For instance, it was reported that Zur in $X$. campestris pv. campestris 8004 positively controls hrp gene expressions via HrpX (Huang et al. 2009). The HrpX-independent genes in the HrpG regulon were as we expected because $\mathrm{HrpG}$ is upstream of HrpX in the regulatory cascade. These genes in the HrpG regulon include 10 regulatory genes and 11 genes related to chemotaxis and flagellar biosynthesis. Those regulatory genes contribute to controlling the large set of genes in the HrpG regulon and also indicate that $\mathrm{HrpG}$ is a master regulator in the pathogenesis process of $X$. axonopodis pv. citri. In addition, we confirmed the repression effect of $\mathrm{HrpG}$ on bacterial motility due to the altered expression of genes involved in chemotaxis and flagellar biosynthesis by testing the motility of the hrpG mutant (Fig. 5).

This study is the first exhaustive genome-wide analysis of HrpG and HrpX regulons in the genus Xanthomonas. We identified a large set of HrpX- or HrpG-dependent unknown or hypothetical proteins that might be candidate virulence genes, particularly multiple ORF in cluster I. This study also provides us a global view of regulation cascades that control the expression of multiple virulence genes, including T3SS, effector, and T2SS substrate genes, during infection. Further microarray analysis of the mutants of the regulatory genes identified in this study will help us explore the regulation circuits of HrpG and HrpX regulons.

\section{MATERIALS AND METHODS}

Strains and growth conditions.

All of the strains used in this study are listed in Supplementary Table S6. X. axonopodis pv. citri wild-type strain 306 was provided by the Division of Plant Industry of the Florida Department of Agriculture and Consumer Services, Gainesville, U.S.A. The $X$. axonopodis pv. citri hrpG mutant was generated in this study as described below and the $h r p X$ mutant was gen- 
erated and confirmed as described in the previous study (Figueiredo et al. 2011). Wild-type strain 306 and mutant strains were grown in nutrient broth (NB), on nutrient agar (NA), or in nutrient yeast gycerol (NYG) medium (Daniels et al. $1984)$ at $28^{\circ} \mathrm{C}$. Escherichia coli strains were grown in LuriaBertani medium at $37^{\circ} \mathrm{C}$. Antibiotics were used at the following concentrations: rifamycin (Rif), $50 \mu \mathrm{g} / \mathrm{ml} ; \mathrm{Km}, 50 \mu \mathrm{g} / \mathrm{ml}$; ampicillin (Ap), $50 \mu \mathrm{g} / \mathrm{ml}$; spectinomycin (Sp), $50 \mu \mathrm{g} / \mathrm{ml}$; gentamicin $(\mathrm{Gm}), 5 \mu \mathrm{g} / \mathrm{ml}$; and chloramphenicol $(\mathrm{Cm}), 35 \mu \mathrm{g} / \mathrm{ml}$.

\section{Generation of the $h r p G$ mutant.}

The 1,180-bp Km-resistance gene kan $\mathrm{R}$ gene was isolated from pBSL15 plasmid by EcoRI digestion and ligated with similarly digested pGEM-T easy vector. The plasmid was named pUSS01-1 when the kanR and lacZ were in the same transcription direction, and the plasmid was named pUSS01-2 when they were not in the same transcription direction. The pUSS01-2 was chosen for further manipulation. The 693-bp upstream region of $h r p G\left(86 \mathrm{bp}\right.$ at $5^{\prime}$ of $\left.h r p G\right)$ was amplified using genomic DNA of $X$. axonopodis pv. citri 306 as template and primers AChrpG-Nde1F3 and AChrpG-NSi1R2, then cleaved with $N d e \mathrm{I}-N s i \mathrm{I}$. The $N d e \mathrm{I}-N s i l \mathrm{I}$ fragment was ligated into similarly digested pUSS01-2. The resulting construct was named phrpGDV1-3', which contains the upstream sequence of $h r p G$ downstream of the Km cassette. The 834-bp fragment containing a 436-bp region downstream of and 398 bp of coding region of $h r p G$ was obtained by ApaI-SphI digestion of the 1,200-bp fragment amplified using genomic DNA of strain 306 as template and primers AChrpG-Apa1F2 and AChrpG-R1. Then, the 834-bp fragment was cloned into phrpGDV1-3' and located upstream of the $\mathrm{Km}$ cassette, which resulted in the construct phrpGDV1 carrying a mutated $h r p G$ fragment consisting of the $\mathrm{Km}$ cassette flanked by $h r p G$ upstream and downstream fragments. The $h r p G$ disruption fragment was cleaved out with BamHI from phrpGDV1 and ligated with BamHI-cut pOK1. The resulting recombination construct, named phrpGDV2, was transformed into E. coli DH5 $\alpha \lambda$ PIR (Huguet et al. 1998) and subsequently transformed into strain 306. Transconjugants were selected on NYG medium supplemented with Rif and Sp. Positive colonies were replicated on both NA plates supplemented with $5 \%$ (wt/vol) sucrose, Sp, and Rif and NA with only Rif. The sucrose-sensitive colonies were selected from NA Rif plate and dilution-plated on NA containing Rif, $\mathrm{Km}$, and 5\% sucrose to select for resolution of the construct by a second cross-over event. The resulting hrpG mutant was confirmed by PCR analysis with three pairs of primers: AChrpG-Kpn1F4 and AChrpG-Kpn1R4, AChrpGApa1F2 and AChrpG-SphR3, and AChrpG-F1 and AChrpGNsi1R2.

\section{Complementation of the $h r p G$ mutant.}

The entire $h r p G$ gene, with a 738-bp upstream sequence and 399-bp downstream sequence, was amplified from genomic DNA of $X$. axonopodis pv. citri wild-type strain 306 using PCR with primers AChrpG-Kpn1F4 and AChrpG-Kpn1R4, which contain a KpnI restriction site. The resulting 1,929-bp fragment was ligated to PCR 2.1-TOPO following the manufacturer's protocol (Invitrogen, Carlsbad, CA, U.S.A.), resulting in phrpG. From phrpG, a KpnI fragment containing the hrp $G$ gene was isolated and cloned into similarly digested pUFR053 that was treated with calf intestinal alkaline phosphatase (New England Biolabs, Ipswich, MA, U.S.A.) (El Yacoubi et al. 2007), resulting in phrpGC. The plasmid phrpGC was transferred into the $h r p G$ mutant by triparental mating with helper E. coli strain containing pRK2013 (Swarup et al. 1991). The transconjugants were selected on NA with Rif and Gm. The presence of phrpGC was verified using PCR.

\section{Pathogenicity assay.}

Pathogenicity assays were conducted in a quarantine greenhouse facility at the Citrus Research and Education Center, Lake Alfred, FL, U.S.A. Assays were performed using fully expanded, immature leaves of Duncan grapefruit (Citrus paradis Macfadyen). X. axonopodis pv. citri wild-type and mutant strains used in this assay were grown with shaking overnight at $28^{\circ} \mathrm{C}$ in $\mathrm{NB}$, centrifuged down, and suspended in sterile tap water, and the concentrations were adjusted to $10^{8} \mathrm{CFU} / \mathrm{ml}$. For the pathogenicity assays, bacterial solutions of both $10^{8}$ and $10^{5} \mathrm{CFU} / \mathrm{ml}$ were infiltrated into leaves with needleless syringes (Rybak et al. 2009; Viloria et al. 2004). The test was repeated three times with similar results. Disease symptoms were photographed at 5,10 , and 12 days postinoculation.

\section{RNA extraction.}

Single bacterial colonies were picked and grown in $5 \mathrm{ml}$ of $\mathrm{NB}$ at $28^{\circ} \mathrm{C}$ for $24 \mathrm{~h}$ with shaking, then transferred into $50 \mathrm{ml}$ of NB for overnight incubation. The bacterial cultures in middle exponential stage were centrifuged down, washed with XVM2 medium once, and inoculated in XVM2 medium with an initial concentration at $\mathrm{OD}_{600}=0.03$. Bacteria were grown in XVM2 medium with shaking at $200 \mathrm{rpm}$ at $28^{\circ} \mathrm{C}$ and samples of culture were collected at three different timepoints: $\mathrm{OD}_{600}$ at $0.25,0.4$, and 0.5 (marked as $\mathrm{A}, \mathrm{B}$, and $\mathrm{C}$, respectively) according to the growth curve in XVM2. Four biological replicates were used for each strain per timepoint. RNA was stabilized immediately by mixing bacterial culture with two volumes of RNAprotect bacterial reagent (Qiagen, Valencia, CA, U.S.A.) and incubated at room temperature for $5 \mathrm{~min}$. Bacterial cells were centrifuged at $5000 \times g$ for $10 \mathrm{~min}$ and cell pellets were used for RNA extraction.

Cell pellets were treated with lysozyme and RNA extractions were performed using a RiboPure bacteria kit (Ambion, Austin, TX, U.S.A.). Contaminated genomic DNA was removed from RNA by treatment with a TURBO DNA-free kit (Ambion). RNA quantity was initially determined on a ND8000 Nanodrop spectrophotometer (NanoDrop Technologies, Wilmington, DE, U.S.A.) and RNA quality was assessed using the Agilent 2100 bioanalyzer (Agilent Technologies, Palo Alto, CA, U.S.A.).

\section{$X$. axonopodis pv. citri oligonucleotide microarray design.}

Based on the annotated genome sequence of $X$. axonopodis pv. citri 306 (da Silva et al. 2002), 8-by-15-K DNA microarray chips covering the whole genome of $X$. axonopodis pv. citri 306 were designed using Agilent's eArray custom design tool and produced by Agilent Technologies. Each of 4,427 proteincoding genes has three unique optimized 60 -mer oligonucleotide probes in microarray. Agilent's standard controls were printed on the array as well, allowing for measurement of proper hybridization conditions.

\section{Microarray hybridization.}

Microarray analysis using the Agilent microarray platform was performed at Interdisciplinary Center for Biotechnology Research Microarray Core Facility, University of Florida. Labeled cDNA was generated using a Fairplay III microarray labeling kit (Agilent Technologies). Total RNA input $(5 \mu \mathrm{g})$ was used to generate labeled cDNA according to the manufacturer's protocol. Briefly, cDNA was synthesized from $5 \mu \mathrm{g}$ of the total RNA with AffinityScript $\mathrm{HC}$ and random primer and then modified cDNA was labeled with either cy3 or cy5; labeled cDNA was purified following the manufacturer's instructions. The microarray analysis was performed using the Agilent 8-by-15-K X. axonopodis pv. citri genome array. Four independent biological replicates were performed for three time- 
point comparisons with dye-swap design. A total of $300 \mathrm{ng}$ of labeled cDNA per sample was used for the hybridization. A dye swap was performed to remove any bias from the labeling dyes. Hybridization was performed using a Gene Expression Hybridization Kit (Agilent Technologies) according to user's manual and was done at hybridization oven for $17.5 \mathrm{~h}$ at $65^{\circ} \mathrm{C}$. The arrays were washed according to the manufacturer's recommended protocols. Briefly, arrays were washed with gene expression wash buffer 1 , containing $0.005 \%$ Triton $\mathrm{X}-102$, for $1 \mathrm{~min}$ at room temperature and were then washed with $37^{\circ} \mathrm{C}$ warmed gene expression wash buffer 2, containing $0.005 \%$ Triton X-102, for $1 \mathrm{~min}$ and were dried by the Agilent Stabilization and Dying Solution. The arrays were scanned using a dual-laser DNA microarray scanner (Model G2505C; Agilent Technologies). The data were extracted from a scanned image using Feature Extraction 10.1.1.1 software (Agilent Technologies).

\section{Microarray data analysis and statistical methods.}

The raw data were imported into $\mathrm{R}$ environment and statistical tests were performed using BioConductor statistical software, which is an open source and open development software project for analysis of microarray and other high-throughput data based primarily on the $\mathrm{R}$ programming language (Gentleman et al. 2004). Data preprocessing and normalization were performed using the Linear Models for Microarray Data (LIMMA) package (Smyth 2004). Raw mean signal intensities from all microarray spots were background corrected and normalized using within-array lowess approach. $\log _{2}$-transformed values were used for statistical analysis. Histograms, box plots, and pairwise scatter plots were generated to examine data quality and comparability. A linear modeling approach and the empirical Bayes statistics as implemented in the LIMMA package (Smyth 2004) were then employed for differential expression analysis. The $P$ values were adjusted using the Benjamini and Hochberg method, designated as FDR (Benjamini and Hochberg 1995). Differentially expressed genes were ranked based on FDR, and genes with FDR $<0.05$ and a minimum absolute value of $\log _{2}$-fold-change $>0.585$ (equivalent to 1.5 -fold) were considered to be significantly differentially expressed. If the gene had three probes and only one was filtered, the gene was removed from further analysis. The $\log _{2}$-fold change values of the differentially expressed genes were averaged from the values of the two or three probes of the corresponding genes. Annotations for the differentially expressed genes were extracted from the Integrated Microbial Genome database and the JCVI database and manually verified. Hierarchical clustering analysis was performed with Cluster 3.0 using complete linking with uncentered correlation distance (de Hoon et al. 2004). The resulting dendograms were visualized using Java Treeview software (Saldanha 2004).

All primary data from transcriptome experiments as well as experimental protocols used are available from Gene Expression Omnibus datasets, the National Center of Biotechnology Information (accession number GSE24016).

\section{QRT-PCR.}

To verify the microarray result, QRT-PCR assays were conducted using the same set of RNA for microarray analysis. Aliquot RNA samples $(1 \mu \mathrm{g})$ used for microarray were reverse transcribed using a RETROscript kit with random hexamer primers (Ambion) for two-step QRT-PCR. Gene-specific primers were designed to generate products 100 to $250 \mathrm{bp}$ in length from sequences on $X$. axonopodis pv. citri genome using DNASTAR software (DNASTAR, Madison, WI, U.S.A.). Real-time PCR was performed for all four biological replicates obtained at timepoint C on a 7500 Fast Real-Time PCR System (Applied Biosystems, Foster City, CA, U.S.A.) using a QuantiTect SYBR Green PCR kit (Qiagen) following the manufacturer's instructions. The $16 \mathrm{~S}$ rRNA and gyrA were used as endogenous controls. The relative fold change of gene expression was calculated by using the formula $2^{-\Delta \Delta C T}$ (Livak and Schmittgen 2001). The values of fold change were $\log _{2}$ transformed to compare with values generated from microarray analysis.

\section{Motility assays.}

The media for motility assays was XVM2 containing $0.3 \%$ agar for swimming and $0.7 \%$ agar for swarming. Bacteria were grown in NB overnight with shaking at $200 \mathrm{rpm}$, and then centrifuged down, washed, and diluted to $\mathrm{OD}_{600}=0.3$ in sterile water. Suspension $(1 \mu \mathrm{l})$ was spotted on the center of each swimming or swarming plate and incubated at room temperature. The assay was repeated three times independently in quadruplicate.

\section{ACKNOWLEDGMENTS}

This work was supported by United States Department of AgricultiureCooperative State Research Education and Extension Services Special Citrus Canker Grant Project 73402. Y. Guo and N. Wang designed and performed research, analyzed data, and wrote the article; F. Figueiredo and $\mathrm{J}$. Jones constructed the hrpX mutant. We thank Y. Zhang and J. Li for their technical help.

\section{LITERATURE CITED}

Alfano, J. R., and Collmer, A. 1996. Bacterial pathogens in plants: Life up against the wall. Plant Cell 8:1683-1698.

Astua-Monge, G., Minsavage, G. V., Stall, R. E., Davis, M. J., Bonas, U., and Jones J. B. 2000. Resistance of tomato and pepper to T3 strains of Xanthomonas campestris pv. vesicatoria is specified by a plant-inducible avirulence gene. Mol. Plant-Microbe Interact. 13:911-921.

Astua-Monge, G., Freitas-Astua, J., Bacocina, G., Roncoletta, J., Carvalho, S. A., and Machado, M. A. 2005. Expression profiling of virulence and pathogenicity genes of Xanthomonas axonopodis pv. citri. J. Bacteriol. 187:1201-1205.

Barber, C. E., Tang, J. L., Feng, J. X., Pan, M. Q., Wilson, T. J., Slater, H., Dow, J. M., Williams, P., and Daniels, M. J. 1997. A novel regulatory system required for pathogenicity of Xanthomonas campestris is mediated by a small diffusible signal molecule. Mol. Microbiol. 24:555-566.

Benjamini, Y., and Hochberg, Y. 1995. Controlling the false discovery rate: A practical and powerful approach to multiple testing. J. R. Stat. Soc. B 57:289-300.

Blanvillain, S., Meyer, D., Boulanger, A., Lautier, M., Guynet, C., Denancé, N., Vasse, J., Lauber, E., and Arlat, M. 2007. Plant carbohydrate scavenging through TonB-dependent receptors: A feature shared by phytopathogenic and aquatic bacteria. PLoS One 2:e224.

Büttner, D., and Bonas, U. 2010. Regulation and secretion of Xanthomonas virulence factors. FEMS (Fed. Eur. Microbiol. Soc.) Microbiol. Rev. 34:107-133

Calhoun, D. H., Bonner, C. A., Gu, W., Xie, G., and Jensen, R. A. 2001 The emerging periplasm-localized subclass of AroQ chorismate mutases, exemplified by those from Salmonella typhimurium and Pseudomonas aeruginosa. Genome Biol. 2:research0030.1-0030.16.

Chan, J. W., and Goodwin, P. H. 1999. The molecular genetics of virulence of Xanthomonas campestris. Biotechnol. Adv. 17:489-508.

Cianciotto, N. P. 2005. Type II secretion: A protein secretion system for all seasons. Trends Microbiol. 13:581-588.

Cubero, J., and Graham, J. H. 2002. Genetic relationship among worldwide strains of Xanthomonas causing canker in citrus species and design of new primers for their identification by PCR. Appl. Environ. Microbiol. 68:1257-1264.

Daniels, M., Barber, C., Turner, P., Sawczyc, M., Byrde, R., and Fielding, A. 1984. Cloning of genes involved in pathogenicity of Xanthomonas campestris pv. campestris using the broad host range cosmid pLAFR1. EMBO (Eur. Mol. Biol. Organ.) J. 3:3323-3328.

da Silva, A. C., Ferro, J. A., Reinach, F. C., Farah, C. S., Furlan, L. R. Quaggio, R. B., Monteiro-Vitorello, C. B., Van Sluys, M. A., Almeida, N. F., Alves, L. M., do Amaral, A. M., Bertolini, M. C., Camargo, L. E., Camarotte, G., Cannavan, F., Cardozo, J., Chambergo, F., Ciapina, L. 
P., Cicarelli, R. M., Coutinho, L. L., Cursino-Santos, J. R., El-Dorry, H., Faria, J. B., Ferreira, A. J., Ferreira, R. C., Ferro, M. I., Formighieri, E. F., Franco, M. C., Greggio, C. C., Gruber, A., Katsuyama, A. M., Kishi, L. T., Leite, R. P., Lemos, E. G., Lemos, M. V., Locali, E. C., Machado, M. A., Madeira, A. M., Martinez-Rossi, N. M., Martins, E. C., Meidanis, J., Menck, C. F., Miyaki, C. Y., Moon, D. H., Moreira, L. M., Novo, M. T., Okura, V. K., Oliveira, M. C., Oliveira, V. R., Pereira, H. A., Rossi, A., Sena, J. A., Silva, C., de Souza, R. F., Spinola, L. A., Takita, M. A., Tamura, R. E., Teixeira, E. C., Tezza, R. I., Trindade dos Santos, M., Truffi, D., Tsai, S. M., White, F. F., Setubal, J. C., and Kitajima, J. P. 2002. Comparison of the genomes of two Xanthomonas pathogens with differing host specificities. Nature 417:459-463.

Degrassi, G., Devescovi, G., Bigirimana, J., and Venturi, V. 2010. Xanthomonas oryzae pv. oryzae XKK.12 contains an AroQ chorismate mutase that is involved in rice virulence. Phytopathology 100:262-270.

de Hoon, M. J., Imoto, S., Nolan, J., and Miyano, S. 2004. Open source clustering software. Bioinformatics 20:1453-1454.

Dharmadi, Y., and Gonzalez, R. 2004. DNA microarrays: Experimental issues, data analysis, and application to bacterial systems. Biotechnol. Progr. 20:1309-1324.

El Yacoubi, B., Brunings, A., Yuan, Q., Shankar, S., and Gabriel, D. W. 2007. In planta horizontal transfer of a major pathogenicity effector gene. Appl. Environ. Microbiol. 73:1612-1621.

Feng, J., Liu, G., Selvaraj, G., Hughes, G. R., and Wei, Y. 2005. A secreted lipase encoded by LIP1 is necessary for efficient use of saturated triglyceride lipids in Fusarium graminearum. Microbiology 151:39113921.

Fenselau, S., and Bonas, U. 1995. Sequence and expression analysis of the hrpB pathogenicity operon of Xanthomonas campestris pv. vesicatoria which encodes eight proteins with similarity to components of the Hrp, Ysc, Spa, and Fli secretion systems. Mol. Plant-Microbe Interact. 8:845-854.

Figueiredo, J. F. L., Minsavage, G. V., Graham, J. H., White, F. F., and Jones, F. B. Mutational analysis of type III effector genes from Xanthomonas citri subsp. citri. Eur. J. Plant Pathol. doi:10.1007/s10658-0119757-7. Published online.

Furutani, A., Tsuge, S., Ohnishi, K., Hikichi, Y., Oku, T., Tsuno, K., Inoue, Y., Ochiai, H., Kaku, H., and Kubo, Y. 2004. Evidence for HrpXo-dependent expression of type II secretory proteins in Xanthomonas oryzae pv. oryzae. J. Bacteriol. 186:1374-1380.

Gentleman, R. C., Carey, V. J., Bates, D. M., Bolstad, B., Dettling, M., Dudoit, S., Ellis, B., Gautier, L., Ge, Y., Gentry, J., Hornik, K., Hothorn, T., Huber, W., Iacus, S., Irizarry, R., Leisch, F., Li, C., Maechler, M., Rossini, A. J., Sawitzki, G., Smith, C., Smyth, G., Tierney, L., Yang, J. Y., and Zhang, J. 2004. Bioconductor: Open software development for computational biology and bioinformatics. Genome Biol. 5:R80.

Gottig, N., Garavaglia, B. S., Daurelio, L. D., Valentine, A., Gehring, C., Orellano, E. G., and Ottado, J. 2009. Modulating host homeostasis as a strategy in the plant-pathogen arms race. Commun. Integr. Biol. 2:89-90.

Graham, J., Gottwald, T., Cubero, J., and Achor, D. 2004. Xanthomonas axonopodis pv. citri: Factors affecting successful eradication of citrus canker. Mol. Plant Pathol. 5:1-15.

Grant, S. R., Fisher, E. J., Chang, J. H., Mole, B. M., and Dangl, J. L. 2006. Subterfuge and manipulation: Type III effector proteins of phytopathogenic bacteria. Annu. Rev. Microbiol. 60:425-449.

He, Y. W., Xu, M., Lin, K., Ng, Y. J., Wen, C.M., Wang, L. H., Liu, Z. D., Zhang, H. B., Dong, Y. H., Dow, J. M., and Zhang, L. H. 2006. Genome scale analysis of diffusible signal factor regulon in Xanthomonas campestris pv. campestris: Identification of novel cell-cell communication-dependent genes and functions. Mol. Microbiol. 59:610-622.

He, Y. W., Ng, A. Y., Xu, M., Lin, K., Wang, L. H., Dong, Y. H., and Zhang, L. H. 2007. Xanthomonas campestris cell-cell communication involves a putative nucleotide receptor protein Clp and a hierarchical signalling network. Mol. Microbiol. 64:281-292.

Huang, D. L., Tang, D. J., Liao, Q., Li, X. Q., He, Y. Q., Feng, J. X., Jiang, B. L., Lu, G. T., and Tang, J. L. 2009. The Zur of Xanthomonas campestris is involved in hypersensitive response and positively regulates the expression of the $h r p$ cluster via $h r p X$ but not $h r p G$. Mol. PlantMicrobe Interact. 22:321-329.

Huguet, E., Hahn, K., Wengelnik, K., and Bonas, U. 1998. hpaA mutants of Xanthomonas campestris pv. vesicatoria are affected in pathogenicity but retain the ability to induce host-specific hypersensitive reaction. Mol. Microbiol. 29:1379-1390.

Joosten, M. H. A. J., Hendrickx, L. J. M., and De Wit, P. J. G. M. 1990. Carbohydrate composition of apoplastic fluids isolated from tomato leaves inoculated with virulent or avirulent races of Cladosporium fulvum (syn. Fulvia fulva). Neth. J. Plant Pathol. 96:103-112.

Koebnik, R., Kruger, A., Thieme, F., Urban, A., and Bonas, U. 2006. Specific binding of the Xanthomonas campestris pv. vesicatoria AraC-type transcriptional activator $\mathrm{HrpX}$ to plant-inducible promoter boxes. J.
Bacteriol. 188:7652-7660.

Leyns, F., De Cleene, M., Swings, J. G., and De Ley, J. 1984. The host range of the genus Xanthomonas. Bot. Rev. 50:308-356.

Livak, K. J., and Schmittgen, T. D. 2001. Analysis of relative gene expression data using real-time quantitative PCR and the $2^{-\triangle \Lambda C T}$ method. Methods 25:402-408.

Manning, G., Plowman, G. D., Hunter, T., and Sudarsanam, S. 2002. Evolution of protein kinase signaling from yeast to man. Trends Biochem. Sci. 27:514-520.

Moreira, L., de Laia, M., de Souza, R., Zaini, P., da Silva, A., da Silva, A., and Ferro, J. 2010a. Development and validation of a Xanthomonas axonopodis pv. citri DNA microarray platform (XACarray) generated from the shotgun libraries previously used in the sequencing of this bacterial genome. BMC Res. Notes 3:150.

Moreira, L. M., Almeida, N. F., Jr., Potnis, N., Digiampietri, L. A., Adi, S. S., Bortolossi, J. C., da Silva, A. C., da Silva, A. M., de Moraes, F. E., de Oliveira, J. C., de Souza, R. F., Facincani, A. P., Ferraz, A. L., Ferro, M. I., Furlan, L. R., Gimenez, D. F., Jones, J. B., Kitajima, E. W., Laia, M. L., Leite, R. P., Jr., Nishiyama, M. Y., Rodrigues Neto, J., Nociti, L. A., Norman, D. J., Ostroski, E. H., Pereira, H. A., Jr., Staskawicz, B. J., Tezza, R. I., Ferro, J. A., Vinatzer, B. A., and Setubal, J. C. 2010 b. Novel insights into the genomic basis of citrus canker based on the genome sequences of two strains of Xanthomonas fuscans subsp. aurantifolii. BMC Genomics 11:238.

Muda, M., Rao, N. N., and Torriani, A. 1992. Role of PhoU in phosphate transport and alkaline phosphatase regulation. J. Bacteriol. 174:80578064.

Neugebauer, H., Herrmann, C., Kammer, W., Schwarz, G., Nordheim, A., and Braun, V. 2005. ExbBD-dependent transport of maltodextrins through the novel MalA protein across the outer membrane of Caulobacter crescentus. J. Bacteriol. 187:8300-8311.

Noël, L., Thieme, F., Nennstiel, D., and Bonas, U. 2001. cDNA-AFLP analysis unravels a genome-wide hrpG-regulon in the plant pathogen Xanthomonas campestris pv. vesicatoria. Mol. Microbiol. 41:1271-1281.

Noël, L., Thieme, F., Nennstiel, D., and Bonas, U. 2002. Two novel type III-secreted proteins of Xanthomonas campestris pv. vesicatoria are encoded within the hrp pathogenicity island. J. Bacteriol. 184:1340-1348.

Oh, H. S., Kvitko, B. H., Morello, J. E., and Collmer, A. 2007. Pseudomonas syringae lytic transglycosylases coregulated with the type III secretion system contribute to the translocation of effector proteins into plant cells. J. Bacteriol. 189:8277-8289.

Osbourn, A. E. 1996. Preformed antimicrobial compounds and plant defense against fungal attack. Plant Cell 8:1821-1831.

Parke, D. 1996. Characterization of PcaQ, a LysR-type transcriptional activator required for catabolism of phenolic compounds, from Agrobacterium tumefaciens. J. Bacteriol. 178:266-272.

Postle, K., and Kadner, R. J. 2003. Touch and go: Tying TonB to transport. Mol. Microbiol. 49:869-882.

Reimmann, C., Beyeler, M., Latifi, A., Winteler, H., Foglino, M., Lazdunski, A., and Haas, D. 1997. The global activator GacA of Pseudomonas aeruginosa PAO positively controls the production of the autoinducer $\mathrm{N}$-butyryl-homoserine lactone and the formation of the virulence factors pyocyanin, cyanide, and lipase. Mol. Microbiol. 24:309-319.

Remenant, B., Coupat-Goutaland, B., Guidot, A., Cellier, G., Wicker, E., Allen, C., Fegan, M., Pruvost, O., Elbaz, M., Calteau, A., Salvignol, G., Mornico, D., Mangenot, S., Barbe, V., Médigue, C., and Prior, P. 2010. Genomes of three tomato pathogens within the Ralstonia solanacearum species complex reveal significant evolutionary divergence. BMC Genomics 11:379.

Rico, A., Jones, R., and Preston, G. M. 2009. Adaptation to the plant apoplast by plant pathogenic bacteria. Pages 63-89 in: Plant-Pathogenic Bacteria: Genomic and Molecular Biology. N. S. Iacobellis, A. Collmer, S. W. Hutcheson, J. W. Mansfield, C. E. Morris, J. Murillo, N. W. Schaad, D. E. Stead, G. Surico, and M. Ullrich, eds. Kluwer Academic Caister Academic Press, Dordrecht, The Netherlands.

Römling, U., Gomelsky, M., and Galperin, M. Y. 2005. C-di-GMP: The dawning of a novel bacterial signalling system. Mol. Microbiol. 57:629639.

Rybak, M., Minsavage, G. V., Stall, R. E., and Jones, J. B. 2009. Identification of Xanthomonas citri ssp. citri host specificity genes in a heterologous expression host. Mol. Plant Pathol. 10:249-262.

Saldanha, A. J. 2004. Java Treeview-extensible visualization of microarray data. Bioinformatics 20:3246-3248.

Sasso, S., Ramakrishnan, C., Gamper, M., Hilvert, D., and Kast, P. 2005. Characterization of the secreted chorismate mutase from the pathogen Mycobacterium tuberculosis. FEBS (Fed. Eur. Biochem. Soc.) J. 272:375-389.

Schaad, N., Postnikova, E., Lacy, G., Sechler, A., Agarkova, I., Stromberg, P., Stromberg, V., and Vidaver, A. 2006. Emended classification of xanthomonad pathogens on citrus. Syst. Appl. Microbiol. 29:690-695. 
Schauer, K., Gouget, B., Carrière, M., Labigne, A., and de Reuse, H. 2007. Novel nickel transport mechanism across the bacterial outer membrane energized by the TonB/ExbB/ExbD machinery. Mol. Microbiol. 63:1054-1068.

Schornack, S., Meyer, A., Römer, P., Jordan, T., and Lahaye, T. 2006 Gene-for-gene-mediated recognition of nuclear-targeted AvrBs3-like bacterial effector proteins. J. Plant Physiol. 163:256-272.

Segura, A., Moreno, M., Madueno, F., Molina, A., and Garcia-Olmedo, F 1999. Snakin-1, a peptide from potato that is active against plant pathogens. Mol. Plant-Microbe Interact. 12:16-23.

Simm, R., Morr, M., Kader, A., Nimtz, M., and Römling, U. 2004 GGDEF and EAL domains inversely regulate cyclic di-GMP levels and transition from sessility to motility. Mol. Microbiol. 53:1123-1134.

Slater, H., Alvarez-Morales, A., Barber, C. E., Daniels, M. J., and Dow, J. M. 2000. A two-component system involving an HD-GYP domain protein links cell-cell signalling to pathogenicity gene expression in Xanthomonas campestris. Mol. Microbiol. 38:986-1003.

Smyth, G. K. 2004. Linear models and empirical Bayes methods for assessing differential expression in microarray experiments. Stat. Appl. Genet. Mol. Biol. 3:Article 3.

Stork, M., Bos, M., Jongerius, I., de Kok, N., Schilders, I., Weynants, V., Poolman, J. T., and Tommassen, J. 2010. An outer membrane receptor of Neisseria meningitidis involved in zinc acquisition with vaccine potential. PLoS Pathog. 6:e1000969.

Swarup, S., Feyter, D. R., Brlansky, R. H., and Gabriel, D. W. 1991. A pathogenicity locus from Xanthomonas citri enables strains from several pathovars of Xanthomonas campestris to elicit canker-like lesions on citrus. Phytopathology 81:802-809.

Tang, J. L., Liu, Y. N., Barber, C. E., Dow, J. M., Wootton, J. C., and Daniels, M. J. 1991. Genetic and molecular analysis of a cluster of rpf genes involved in positive regulation of synthesis of extracellular enzymes and polysaccharide in Xanthomonas campestris pathovar campestris. Mol. Gen. Genet. 226:409-417.

Tischler, A. D., and Camilli, A. 2004. Cyclic diguanylate (c-di-GMP) regulates Vibrio cholerae biofilm formation. Mol. Microbiol. 53:857869.

Tseng, G., Oh, M., Rohlin, L., Liao, J., and Wong, W. 2001. Issues in cDNA microarray analysis: Quality filtering, channel normalization, models of variations and assessment of gene effects. Nucleic Acids Res. 29:2549-2557.

Vauterin, L., Hoste, B., Kersters, K., and Swings, J. 1995. Reclassification of Xanthomonas. Int. J. Syst. Bacteriol. 45:472-489.

Viloria, Z., Drouillard, D. L., Graham, J. H., and Grosser, J. W. 2004. Screening triploid hybrids of 'Lakeland' limequat for resistance to citrus canker. Plant Dis. 88:1056-1060.

Wang, L., Rong, W., and He, C. 2008. Two Xanthomonas extracellular polygalacturonases, PghAxc and $\mathrm{PghBxc}$, are regulated by type III secretion regulators $\mathrm{HrpX}$ and $\mathrm{HrpG}$ and are required for virulence. Mol. Plant-Microbe Interact. 21:555-563.

Wei, K., Tang, D. J., He, Y. Q., Feng, J. X., Jiang, B. L., Lu, G. T., Chen,
B., and Tang, J. L. 2007. hpaR, a putative marR family transcriptional regulator, is positively controlled by $\mathrm{HrpG}$ and $\mathrm{HrpX}$ and involved in the pathogenesis, hypersensitive response, and extracellular protease production of Xanthomonas campestris pathovar campestris. J. Bacteriol. 189:2055-2062.

Wengelnik, K., and Bonas, U. 1996. HrpXv, an AraC-type regulator, activates expression of five of the six loci in the hrp cluster of Xanthomonas campestris pv. vesicatoria. J. Bacteriol. 178:3462-3469.

Wengelnik, K., Marie, C., Russel, M., and Bonas, U. 1996a. Expression and localization of HrpA1, a protein of Xanthomonas campestris pv. vesicatoria essential for pathogenicity and induction of the hypersensitive reaction. J. Bacteriol. 178:1061-1069.

Wengelnik, K., Van den Ackerveken, G., and Bonas, U. 1996b. HrpG, key hrp regulatory protein of Xanthomonas campestris pv. vesicatoria is homologous to two-component response regulators. Mol. PlantMicrobe Interact. 9:704-712.

Wengelnik, K., Rossier, O., and Bonas, U. 1999. Mutations in the regulatory gene hrpG of Xanthomonas campestris pv. vesicatoria result in constitutive expression of all hrp genes. J. Bacteriol. 181:6828-6831

Xia, T., Song, J., Zhao, G., Aldrich, H., and Jensen, R. A. 1993. The aroQencoded monofunctional chorismate mutase (CM-F) protein is a periplasmic enzyme in Erwinia herbicola. J. Bacteriol. 175:4729-4737.

Yamazaki, A., Hirata, A., and Tsuyumu, S. 2008. HrpG regulates type II secretory proteins in Xanthomonas axonopodis pv. citri. J. Gen. Plant Pathol. 74:138-150.

Yang, T. C., Leu, Y. W., Chang-Chien, H. C., and Hu, R. M. 2009. Flagellar biogenesis of Xanthomonas campestris requires the alternative sigma factors RpoN2 and FliA and is temporally regulated by FlhA, FlhB, and FlgM. J. Bacteriol. 191:2266-2275.

Ye, R. W., Wang, T., Bedzyk, L., and Croker, K. M. 2001. Applications of DNA microarrays in microbial systems. J. Microbiol. Methods 47:257272.

Zhang, Y., Callaway, E. M., Jones, J. B., and Wilson, M. 2009. Visualisation of hrp gene expression in Xanthomonas euvesicatoria in the tomato phyllosphere. Eur. J. Plant. Pathol. 124:379-390.

\section{AUTHOR-RECOMMENDED INTERNET RESOURCES}

BioConductor website: www.bioconductor.org

Gene Expression Omnibus (GEO) database: www.ncbi.nlm.nih.gov/geo

The Integrated Microbial Genome (IMG) Xanthomonas axonopodis pv. citri 306 genome database: img.jgi.doe.gov/cgi-bin/pub/main.cgi?section=TaxonDetail\&page= taxonDetail\&taxon_oid=637000342

The J. Craig Venter Institute (JCVI) Xanthomonas axonopodis pv. citri 306 genome database: cmr.jcvi.org/tigr-scripts/CMR/GenomePage.cgi?database $=$ ntxa01

Pfam website: pfam.janelia.org

Phobius website: http://phobius.sbc.su.se 